\title{
PERBEDAAN TEKANAN DARAH SEBELUM DAN SESUDAH TERPAPAR KEBISINGAN DI AREA FABRIKASI BAJA GRESIK TAHUN 2020
}

\author{
Rohmatul Ummah, Winarko*, Rusmiati
}

Jurusan Kesehatan Lingkungan Poltekkes Kemenkes Surabaya

*Email korespondensi: winarko0202@gmail.com

\begin{abstract}
ABSTRAK
Kebisingan sebagai suara yang tidak dikehendaki bersumber proses produksi dan atau alat-alat kerja yang pada tingkat tertentu dapat menimbulkan gangguan pendengaran (auditory) dan gangguan non pendengaran (non auditory). Gangguan non pendengaran (non auditory) salah satunya berupa peningkatan sistem kardiovaskuler yang dapat menyebabkan naiknya tekanan darah sistole dan diastole. Penelitian ini bertujuan untuk mengetahui perbedaan tekanan darah pekerja sebelum dan sesudah terpapar kebisingan di area fabrikasi baja Gresik.

Rancang bangun penelitian ini termasuk jenis observasional dengan pendekatan waktu pengumpulan dilakukan secara cross sectional. Besar sampel sebanyak 28 pekerja diambil secara random dari 30 pekerja. Data dikupulkan melalui observasi, wawancara dan pengukuran. Data yang yang terkumpul diolah dan dianalisis menggunakan program SPSS melalui uji T (Paired Sample T-Test) alpha 0,05.

Hasil penelitian menunjukkan bahwa intensitas kebisingan di area fabrikasi baja melebihi Nilai Ambang Batas (NAB) yaitu sebesar > $85 \mathrm{dBA}$, ada perbedaan yang signifikan antara tekanan darah sistole dan diastole sebelum terpapar kebisingan dengan tekanan darah sistole dan diastole sesudah terpapar kebisingan dengan nilai nilai $p=0,000(p<$ $0,05)$ dan secara diskriptif tekanan darah tidak memenuhi syarat dipengaruhi oleh umur dan masa kerja, sedangkan kebiasaan kebiasaan merokok dan minuman beralkohol tidak berpengaruh.

Disarankan kepada perusahaan untuk melakukan pengendalian sumber kebisingan dan mewajibkankan penggunaan Alat Pelindung Diri serta memberikan pelatihan dan penyuluhan kepada tenaga kerja mengenai kesehatan dan keselamatan kerja, mengingat tingkat kesadaran tenaga kerja mengenai pentingnya keselamatan dan kesehatan kerja masih kurang.
\end{abstract}

Kata Kunci: Kebisingan, Tekanan Darah dan Area Fabrikasi Baja Gresik

\section{PENDAHULUAN}

Perkembangan industri di Indonesia telah mengalami kemajuan yang sangat pesat, hampir semua industri menggunakan mesin yang dapat menimbulkan suara yang keras yang dapat menjadi sumber kebisingan. Perkembangan industri ini diikuti dengan bertambahnya jumlah pekerja sehingga semakin bertambah jumlah tenaga kerja yang terpapar kebisingan. Sumber kebisingan yang tidak dikontrol dilakukan pengecekan, maka dapat menimbulkan masalah atau menyebabkan timbulnya penyakit akibat kerja, seperti : terganggunya kenyamanan dan kesehatan pekerja (Albustomi \& W, 2017).

Pekerjaan yang dilakukan setiap tenaga kerja memiliki potensi bahaya atau hazard yang dapat menyebabkan kecelakaan atau penyakit akibat kerja.
Oleh karena itu, bagi tenaga kesehatan sebaiknya lebih banyak memperhatikan aspek kesehatan kerja. Keselamatan dan kesehatan kerja merupakan aspek penting dalam produktifitas kerja. Lingkungan kerja industri yang sehat merupakan salah satu faktor yang dapat menunjang peningkatan kinerja dan dapat menurunkan risiko terhadap gangguan kesehatan serta penyakit akibat kerja dalam proses produksi yang dilakukan secara bersamaan.

Menurut Permenkes RI Nomor 70 tahun 2016 tentang Standar dan Persyaratan Kesehatan Lingkungan Kerja Industri bahwa lingkungan kerja industri harus memenuhi standar dan persyaratan kesehatan lingkungan kerja industri sebagai persyaratan minimal yang harus dipenuhi. Standar dan persyaratan 
kesehatan lingkungan kerja industri terdiri atas nilai ambang batas, indikator pajanan biologi, dan persyaratan kesehatan lingkungan kerja industri, salah satunya faktor fisika.

Faktor fisika dalam Permenaker RI Nomor 5 tahun 2018 tentang Keselamatan dan Kesehatan Lingkungan Kerja, adalah faktor yang dapat mempengaruhi aktivitas tenaga kerja di lingkungan kerja yang dapat mempengaruhi aktivitas tenaga kerja yang bersifat fisika yang disebabkan oleh penggunaan mesin, peralatan, bahan dan kondisi lingkungan di tempat kerja yang dapat menyebabkan gangguan penyakit akibat kerja pada tenaga kerja meliputi iklim kerja, kebisingan, getaran, radiasi gelombang mikro, radiasi gelombang ultra ungu (ultra violet) radiasi medan magnet statis, tekanan udara, dan pencahayaan. Faktor tersebut dapat menimbulkan masalah atau menyebabkan timbulnya penyakit akibat kerja.

Penyakut akibat kerja pada peningkatan tekanan darah juga dapat disebabkan kondisi fisik lingkungan lainnya, seperti tekanan panas. Hal ini terbukti dalam penelitian yang dilakukan Novi Nur Pratiwi dkk. (2017), terbukti bahwa perbedaan tekanan darah sebelum dan sesudah terpapar panas yaitu tekanan darah sistolik 0,001 dan diastolik $0,000 \quad(\leq 0,05)$, sehingga menarik untuk diketahui juga pengaruh kebisungan terhadap tekanan darah pekerja.

Permasalahan yang masih dirasakan dan sering terjadi di tempat kerja berupa gangguan fisik maupun psikis yang mengganggu kenyamanan dan kesehatan pekerja. Lingkungan kerja yang nyaman sangat dibutuhkan manusia untuk dapat beraktivitas secara optimal dan produktif. Salah satu gangguan fisik yang terjadi di tempat kerja adalah kebisingan (Setiyanto, 2013).

Menurut Peraturan Menteri Ketenagakerjaan RI No. 5 tahun 2018 tentang Keselamatan dan Kesehatan Kerja Lingkungan Kerja, Kebisingan adalah semua suara yang tidak dikehendaki yang bersumber dari alat-alat proses produksi dan atau alat-alat kerja yang pada tingkat tertentu dapat menimbulkan gangguan pendengaran. Pengaruh utama terpapar kebisingan yang tinggi adalah kehilangan pendengaran akibat dari imbas bising (noise induced hearing loss). Kebisingan yang berlebihan juga dapat menyebabkan kepenatan (fatigue) dan disorientasi. Pekerja yang terpapar bising di tempat kerja dan terpapar oleh mesin yang memiliki suara bising seperti mesin bubut, grinda dapat menimbulkan efek visceral seperti perubahan frekuensi jantung, tingkat pengeluaran keringat, dan perubahan tekanan darah (Harrington, 2003 ).

Selain berpengaruh terhadap gangguan pendengaran (auditory), kebisingan pada intensitas yang tinggi juga dapat menyebabkan gangguan non pendengaran (non auditory). Gangguan pendengaran yang terjadi yaitu tinnitus atau telinga berdengung dan ketulian atau NIHL (Noise Induced Hearing Loss), sedangkan gangguan non pendengaran atau non auditory yang biasa terjadi yaitu gangguan tidur, gangguan sistem kardiovaskular, dan penurunan daya kognitif anak (Muhammad Amin, Rita Rosari, 2019)

Kebisingan pada intensitas yang tinggi juga dapat menyebabkan gangguan terhadap mental emosional seperti terganggunya kenyamanan dalam bekerja, mudah tersinggung, dan mudah marah serta dapat menimbulkan gangguan pada sistem jantung dan peredaran darah. Melalui mekanisme hormonal yaitu di produksinya hormon adrenalin yang dapat menyebabkan meningkatnya frekuensi detak jantung dan peningkatan tekanan darah. Hal ini termasuk gangguan kardiovaskuler (Sasongko, 2000).

Peningkatan sistem kardiovaskuler dapat menyebabkan naiknya tekanan darah sistole dan diastole. Perubahan tekanan darah terjadi akibat dari terpapar intensitas kebisingan yang tinggi sehingga dapat menyebabkan ketidakstabilan hormon epinerin, non epinerin, dan kortisol tubuh yang dapat menimbulkan ternyadinya perubahan pada detak jantung dan tekanan darah (Hidayat, 2004). Salah satu penyakit pada sistem 
kardiovaskular adalah hypertensi atau terjadinya peningkatan tekanan darah. Hasil dari survey pendahuluan yang telah dilakukan oleh peneliti di area fabrikasi baja PT. Bangun Sarana Baja Gresik didapatkan hasil bahwa dari 10 pekerja yang dijadikan sampel sementara, pekerja mengalami perubahan tekanan darah setelah bekerja terpapar kebisingan dengan intensitas yang tinggi. Satu pekerja diantaranya memiliki riwayat penyakit tekanan darah tinggi (hipertensi) dengan tekanan darah sistole sebelum bekerja $130 \mathrm{mmHg}$ dan tekanan darah diastole sebelum bekerja $70 \mathrm{mmHg}$. Setelah bekerja pada intensitas kebisingan yang tinngi, tekanan darah sistole sesudah bekerja $140 \mathrm{mmHg}$ dan tekanan darah diastole sebelum bekerja $85 \mathrm{mmHg}$. Sedangkan 9 orang pekerja tidak memiliki riwayat penyakit tekanan darah tinggi (hipertensi) dengan tekanan darah sistole $<120 \mathrm{mmHg}$ dan diastole < $80 \mathrm{mmHg}$. Perubahan tekanan darah terjadi karena akibat dari terpapar intensitas kebisingan yang tinggi dalam waktu yang lama.

Penelitian yang dilakukan oleh (Paramita, 2012) di PT PJB Gresik didapatkan bahwa ada pengaruh intensitas kebisingan terhadap kenaikan tekanan darah. Penelitian ini menyebutkan bahwa resiko pekerja yang terpapar bising mengalami kenaikan tekanan darah 1,647 kali daripada pekerja yang tidak terpapar bising. Hal ini juga ditunjukkan lebih dari 70 persen pekerja mengalami kenaikan tekanan darah dari saat sebelum dan setelah terpapar bising.

Menurut Boedhi Raharjani dalam jurnal penelitian (Rosidah, 2005), pada pekerja PT. Kereta Api Indonesia didapatkan hasil yaitu tekanan darah sebelum kerja rata-rata dalam batas normal, namun sesudah kerja dicatat adanya kenaikan tekanan darah baik sistole maupun diastole. Keadaan ini diduga kuat bukan disebabkan oleh beban kerja masinis, tetapi lebih banyak dipengaruhi oleh faktor tingginya tingkat kebisingan di dalam kabin kerja masinis Menurut Albustomi dkk (2017) mengatakan bahwa pada penelitian yang dilakukan di tempat kerja PT. Semen Tonasa didapatkan hasil bahwa pada lingkungan kerja bagian teknik unloading crane, crusherbatu kapur unit IV, raw mill (unit II, III, dan IV), coal mill, cement mill, dan packing plant memiliki intensitas kebisingan yang tinggi sehingga mengakibatkan pekerja mengalami peningkatan tekanan darah. Rata-rata kenaikan tekanan darah sistole yaitu sebesar 19,2 mmHg dan diastole yaitu sebesar $6,8 \mathrm{mmHg}$. Pengukuran dilakukan sebelum dan sesudah bekerja.

Nilai Ambang Batas (NAB) faktor fisik/kimia menurut Peraturan Menteri Kesehatan RI No. 70 tahun 2016 tentang Standar dan Persyaratan Kesehatan Lingkungan Kerja Industri adalah intensitas/konsentrasi rata-rata pajanan bahaya fisik/kimia yang dapat diterima oleh hampir semua pekerja tanpa mengakibatkan gangguan kesehatan atau penyakit atau penyakit dalam pekerjaan sehari-hari. Dalam peraturan tersebut ditetapkan Nilai Ambang Batas (NAB) kebisingan sebesar $85 \mathrm{dBA}$ untuk waktu yang tidak melebihi 8 jam sehari atau 40 jam seminggu.

Terdapat beberapa tahapan dalam proses produksi baja yang dilakukan oleh tenaga kerja di PT. Bangun Sarana Baja antara lain, proses pemberian tanda dan pemotongan material (marking-cutting), proses pembuatan lubang pada benda kerja sesuai tandanya (drilling), proses menyatukan bahan material (fitting/assembly), proses pengelasan (welding) dan finishing. Faktor lingkungan fisik yang paling berpengaruh pada area fabrikasi baja adalah kebisingan, karena mesin dan peralatan yang digunakan menimbulkan bunyi yang dapat menyebabkan kebisingan. Pekerja yang terpapar kebisingan terlalu lama mengalami gangguan non auditory salah satunya adalah peningkatan tekanan darah.

Hasil dari survey pendahuluan yang telah dilakukan di PT. Bangun Sarana Baja Gresik pada area fabrikasi baja Gudang 2 diketahui bahwa hasil pengukuran intensitas sebesar 90,7 dBA dan pada area painting intensitas kebisingan $82,4 \mathrm{dBA}$ dengan waktu kerja 8 jam/hari. Dalam Peraturan Menteri Ketenagakerjaan RI No. 5 tahun 2018 disebutkan bahwa intensitas kebisingan dengan level 
kebisingan 95 dBA hanya diperbolehkan untuk durasi pajanan kebisingan 1 jam/hari. Sedangkan NAB (Nilai Ambang Batas) untuk 8 jam/hari adalah sebesar 85 dBA.

Penelitian ini bertujuan untuk menganalisis perbedaan tekanan darah sebelum dan sesudah terpapar kebisingan pada tenaga kerja di area fabrikasi baja, dan menganalisis pengaruh dan pengaruh umur, lama bekerja, kebiasaan merokok, dan kebiasaan minum beralkohol terhadap tekanan darah.

\section{METODE PENELITIAN}

Rancang bangun penelitian ini termasuk jenis observasional dengan pendekatan waktu pengumpulan dilakukan secara cross sectional. Besar sampel sebanyak 28 pekerja diambail secara random dari 30 pekerja. Data dikumpulkan melalui observasi, wawancara dan pengukuran Data yang yang terkumpul diolah dan dianalisis menggunakan program SPSS melalui uji T (Paired Sample T-Test) alpha 0,05.

\section{HASIL PENELITIAN}

Tabel 1

Distribusi frekuensi pekerja menurut umur di PT. Bangun Sarana Baja Gresik Tahun 2020

\begin{tabular}{cccc}
\hline No & $\begin{array}{c}\text { Umur } \\
\text { (Tahun) }\end{array}$ & Frekuensi & Presentase (\%) \\
\hline 1. & $<40$ & 17 & 60 \\
\hline 2. & $\geq 40$ & 11 & 40 \\
\hline & Total & 28 & 100 \\
\hline
\end{tabular}

Umur pekerja di PT. Bangun Sarana Baja Gresik 60\% kurang dari 40 tahun dan $40 \%$. Berumur lebih besar atau sama dengan 40 tahun.

Tabel 2

Distribusi frekuensi pekerja menurut masa kerja di PT. Bangun Sarana Baja Gresik Tahun 2020

\begin{tabular}{cccc}
\hline No & $\begin{array}{c}\text { Masa Bekerja } \\
\text { (Tahun) }\end{array}$ & Frekuensi & Presentase (\%) \\
\hline 1. & $<5$ & 9 & 32 \\
\hline 2. & $5-10$ & 12 & 43 \\
\hline 3. & $>10$ & 7 & 25 \\
\hline & Total & 28 & 100 \\
\hline
\end{tabular}

Masa kerja tenaga kerja di area fabrikasi baja PT. Bangun Sarana Baja Gresik kurang dari 5 tahun 32\%, 5 - 10 tahun $43 \%$ dan masa kerja lebih dari 10 tahun 25\%.

Tabel 3

Distribusi frekuensi pekerja menurut kebiasaan merokok di PT. Bangun Sarana Baja Gresik Tahun 2020

\begin{tabular}{cccc}
\hline No & $\begin{array}{c}\text { Kebiasaan } \\
\text { Merokok }\end{array}$ & Frekuensi & Presentase (\%) \\
\hline 1. & Merokok & 21 & 75 \\
\hline 2. & Tidak Merokok & 7 & 25 \\
\hline & Total & 28 & 100 \\
\hline
\end{tabular}

Kebiasaan merokok pekerja di PT. Bangun Sarana Baja Gresik 75\% merokok dan 25\% tidak merokok. 
Tabel 4

Distribusi frekuensi pekerja menurut kebiasaan minum beralkohol di PT. Bangun Sarana Baja Gresik Tahun 2020

\begin{tabular}{cccc}
\hline No & $\begin{array}{c}\text { Kebiasaan } \\
\text { Minum } \\
\text { Beralkohol }\end{array}$ & Frekuensi & Presentase (\%) \\
\hline 1. & Minum & 4 & 15 \\
\hline 2. & Tidak Minum & 24 & 85 \\
\hline & Total & 28 & 100 \\
\hline
\end{tabular}

Pekerja di PT. Bangun Sarana Baja Gresik memiliki kebiasaan tidak minum minuman beralkohol sebanyak $85 \%$ dan $15 \%$ memiliki kebiasaan minum munuman berakohol

Tabel 5

Hasil Pengukuran Intensitas Kebisingan di Area Fabrikasi Baja PT. Bangun Sarana Baja Gresik Tahun 2020

\begin{tabular}{cccccc}
\hline No. & $\begin{array}{c}\text { Lokasi } \\
\text { Pengukuran }\end{array}$ & $\begin{array}{c}\text { Jam } \\
\text { (WIB) }\end{array}$ & $\begin{array}{c}\text { Intensitas } \\
\text { Kebisingan } \\
\text { (dBA) }\end{array}$ & $\begin{array}{c}\text { MS / } \\
\text { TMS }\end{array}$ & $\begin{array}{c}\text { Jumlah } \\
\text { Pekerja } \\
\text { (Orang) }\end{array}$ \\
\hline 1. & Gudang 2 & 09.14 & 85,9 & TMS & 5 \\
\hline 2. & Gudang 3 & 09.33 & 86,6 & TMS & 5 \\
\hline 3. & Gudang 4 & 09.48 & 89,7 & TMS & 6 \\
\hline 4. & Gudang 1 & 10.07 & 88,7 & TMS & 6 \\
\hline 5. & Gudang 12 & 10.20 & 87,2 & TMS & 6 \\
\hline
\end{tabular}

Hasil pengukuran intensitas kebisingan menunjukan hasil berkisar 85,9 dBA s/d 89,7 dBA dan $100 \%$ telah melebihi NAB (Permenaker RI No.5 tahun 2018 tentang K3 Lingkungan Kerja), yaitu sebesar $85 \mathrm{dBA}$ untuk waktu pemaparan 8 jam per hari.

\section{Perbedaan Tekanan Darah Sebelum dan Sesudah Terpapar Kebisingan}

\section{Tabel 6}

Hasil pengukuran tekanan darah pekerja sebelum dan sesudah terpapar kebisingan di PT. Bangun Sarana Baja Gresik Tahun 2020.

\begin{tabular}{ccccccc}
\hline Nama Responden & \multicolumn{3}{c}{ Tekanan Darah Sistole } & \multicolumn{3}{c}{ Tekanan Darah Diastole } \\
\cline { 2 - 7 } & Sebelum & Sesudah & Selisih & Sebelum & Sesudah & Selisih \\
\hline R1 & 120 & 140 & 20 & 65 & 80 & 20 \\
\hline R2 & 130 & 140 & 10 & 78 & 90 & 12 \\
\hline R3 & 110 & 120 & 10 & 77 & 90 & 13 \\
\hline R4 & 130 & 140 & 10 & 80 & 90 & 10 \\
\hline R5 & 117 & 118 & 1 & 64 & 65 & 1 \\
\hline R6 & 120 & 133 & 13 & 65 & 66 & 1 \\
\hline R7 & 120 & 135 & 15 & 65 & 85 & 20 \\
\hline R8 & 121 & 128 & 7 & 68 & 85 & 17 \\
\hline R9 & 122 & 139 & 17 & 70 & 90 & 20 \\
\hline R10 & 122 & 131 & 9 & 70 & 84 & 14 \\
\hline R11 & 130 & 140 & 10 & 64 & 81 & 17 \\
\hline R12 & 123 & 135 & 12 & 78 & 87 & 9 \\
\hline R13 & 119 & 123 & 4 & 75 & 90 & 15 \\
\hline R14 & 130 & 140 & 10 & 68 & 90 & 22 \\
\hline R15 & 100 & 128 & 28 & 70 & 80 & 10 \\
\hline R16 & 120 & 120 & 0 & 70 & 91 & 21 \\
\hline R17 & 128 & 146 & 18 & 80 & 97 & 17 \\
\hline
\end{tabular}




\begin{tabular}{ccccccc}
\hline Nama Responden & \multicolumn{3}{c}{ Tekanan Darah Sistole } & \multicolumn{2}{c}{ Tekanan Darah Diastole } \\
\hline & Sebelum & Sesudah & Selisih & Sebelum & Sesudah & Selisih \\
\hline R18 & 130 & 138 & 8 & 78 & 88 & 10 \\
\hline R19 & 129 & 140 & 11 & 70 & 88 & 10 \\
\hline R20 & 120 & 138 & 18 & 69 & 81 & 12 \\
\hline R21 & 116 & 125 & 9 & 70 & 80 & 10 \\
\hline R22 & 120 & 128 & 8 & 64 & 75 & 11 \\
\hline R23 & 126 & 130 & 4 & 60 & 68 & 8 \\
\hline R24 & 140 & 153 & 13 & 70 & 95 & 25 \\
\hline R25 & 133 & 140 & 7 & 68 & 80 & 12 \\
\hline R26 & 130 & 135 & 5 & 80 & 100 & 20 \\
\hline R27 & 110 & 120 & 10 & 65 & 90 & 25 \\
\hline R28 & 120 & 140 & 20 & 70 & 98 & 20 \\
\hline
\end{tabular}

Tekanan darah tenaga kerja sistole sebelum dan sesudah terpapar kebisingan terjadi peningkatan berkisar antara $1 \mathrm{~s} / \mathrm{d}$ $20 \mathrm{mmHg}$ dengan rata-rata $11 \mathrm{mmHg}$, sedangkan tekanan darah diastole terjadi peningkatan setelah terpapar kebisingan berkisar antara $1 \mathrm{~s} / \mathrm{d} 25 \mathrm{mmHg}$ dengan rata-rata $14 \mathrm{mmHg}$. Berdasar table 6 tersebut dapat disimpulkan bahwa paparan kebisingan yang melebihi NAB daoat meningkatkan tekanan darah tenaga kerja.
Berdasarkan hasil uji statistik tentang perbedaan tekanan darah sistole menggunakan Paired Sample T-Testalpha $5 \%(0,05)$ didapat hasil nilai $\mathrm{P}=0,000(\leq$ $0,05)$, maka $\mathrm{H}_{0}$ ditolak, sehingga dapat dsimpulkan ada perbedaan yang signifikan antara tekanan darah sistole sebelum terpapar kebisingan dengan tekanan darah sistolik sesudah terpapar kebisingan pada pekerja di PT. Bangun Sarana Baja Gresik (table 7) berikut ini.

Tabel 7

Perbedaan Tekanan Darah Sistole Sebelum dan Sesudah Terpapar Kebisingan Pada Pekerja di PT. Bangun Sarana Baja Gresik Tahun 2020

\begin{tabular}{cccccc}
\hline No. & Variabel & $\mathbf{T}$ & $\mathbf{d F}$ & $\begin{array}{c}\text { Sig } \\
\text { (2-tailed) }\end{array}$ & Mean \\
\hline 1. & $\begin{array}{c}\text { Tekanan darah } \\
\text { sistole sebelum } \\
\text { dan sesudah } \\
\text { terpapar } \\
\text { kebisingan. }\end{array}$ & $-9,398$ & 27 & 0,000 & $-10,964$ \\
\hline
\end{tabular}

Berdasarkan hasil uji statistik tentang perbedaan tekanan darah diastole menggunakan Paired Sample TTest alpha $5 \%(0,05)$ didapat hasil nilai $\mathrm{p}=0,000 \quad(\leq 0,05)$, maka $\mathrm{H}_{0}$ ditolak, sehingga dapat disimpulkan ada perbedaan yang signifikan antara tekanan darah diastole sebelum terpapar kebisingan dengan tekanan darah sistolik sesudah terpapar kebisingan pada pekerja di PT. Bangun Sarana Baja Gresik (table 8) berikut ini.

Tabel 8

Perbedaan Tekanan Darah Diastole Sebelum dan Sesudah Terpapar Kebisingan Pada Pekerja di PT. Bangun Sarana Baja Gresik Tahun 2020

\begin{tabular}{cccccc}
\hline No. & Variabel & $\mathbf{T}$ & $\mathbf{d F}$ & $\begin{array}{c}\text { Sig } \\
\text { (2-tailed) }\end{array}$ & Mean \\
\hline 1. & $\begin{array}{c}\text { Tekanan darah } \\
\text { diastole sebelum } \\
\text { dan sesudah } \\
\text { terpapar kebisingan. }\end{array}$ & $-4,985$ & 27 & 0,000 & $-10,714$ \\
\hline
\end{tabular}




\section{Pengaruh Umur, Masa Kerja, Kebiasaan Merokok dan Minuman Berakohol Terhadap Perubahan Tekanan Darah}

Tabel 9

Pengaruh Umur Terhadap Perubahan Tekanan Darah Pekerja Pada Area Fabrikasi Baja di PT. Bangun Sarana Baja Gresik Tahun 2020.

\begin{tabular}{cccccccc}
\hline & & \multicolumn{7}{c}{ Tekanan Darah } \\
\cline { 3 - 6 } No & Umur & \multicolumn{2}{c}{ MS } & \multicolumn{2}{c}{ TMS } & Jumlah & $\%$ \\
\cline { 3 - 7 } & (Tahun) & $\mathbf{n}$ & $\mathbf{\%}$ & $\mathbf{N}$ & $\mathbf{\%}$ & & \\
\hline 1. & $\leq 40$ & 2 & $12 \%$ & 15 & $88 \%$ & 17 & $100 \%$ \\
\hline 2. & $>40$ & 0 & $0 \%$ & 11 & $100 \%$ & 11 & $100 \%$ \\
\hline
\end{tabular}

Secara diskriptif bahwa tekanan daran tidak memenuhi syarat $100 \%$ dialami oleh bekerja berumur pekerja yang berumur $>40$ tahun dibanding dengan yang berumur $\leq 40$ tahun sebanyak $88 \%$.

Pengaruh masa kerja terhadap tekanan darah pekerja sebagaimana tersebut pada table 10 , secara diskriptif dapat disimpulkan bahwa tekanan darah tidak memenuhi syarat (100 \%) banyak dialami oleh pekerja yang memilikimasa kerja lebih dari $\geq 5$ tahun, sedangkan tekanan darah tidak normar sebesar $89 \%$ terjadi pada pekerja kurang dari $<5$ tahun (table 10) berikut ini.

Tabel 10

Pengaruh Masa Kerja Terhadap Perubahan Tekanan Darah Pekerja Pada Area Fabrikasi Baja di PT. Bangun Sarana Baja Gresik Tahun 2020.

\begin{tabular}{ccccccccc}
\hline \multirow{2}{*}{ No } & $\begin{array}{c}\text { Masa } \\
\text { Kerja }\end{array}$ & \multicolumn{7}{c}{ Tekanan Darah } \\
\cline { 3 - 7 } & (Tahun) & $\mathbf{n}$ & $\mathbf{\%}$ & $\mathbf{N}$ & $\mathbf{\%}$ & & \\
\hline 1. & $<5$ & 1 & $11 \%$ & 8 & $89 \%$ & 9 & $100 \%$ \\
\hline 2. & $5-10$ & 0 & $0 \%$ & 12 & $100 \%$ & 12 & $100 \%$ \\
\hline 3. & $>10$ & 0 & $0 \%$ & 7 & $100 \%$ & 7 & $100 \%$ \\
\hline
\end{tabular}

Tabel 11

Pengaruh Kebiasaan Merokok Terhadap Perubahan Tekanan Darah Pekerja Pada Area Fabrikasi Baja di PT. Bangun Sarana Baja Gresik Tahun 2020.

\begin{tabular}{cccccccc}
\hline & & \multicolumn{7}{c}{ Tekanan Darah } \\
\cline { 3 - 6 } No & $\begin{array}{c}\text { Kebiasaan } \\
\text { Merokok }\end{array}$ & $\mathbf{n}$ & $\mathbf{\%}$ & $\mathbf{N}$ & $\mathbf{\%}$ & & \\
\hline 1. & Ya & 3 & $14 \%$ & 18 & $86 \%$ & 21 & $100 \%$ \\
\hline 2. & Tidak & 1 & $14 \%$ & 6 & $86 \%$ & 7 & $100 \%$ \\
\hline
\end{tabular}

Kebiasaan merokok pada pekerja dapat diketahu tekanan darah tidak memenuhi syarat antara perokok dan bukan perokok sama-sama memiliki tekanan darah tidak memenuhui syarat sebanyak $86 \%$, sehingga dapat disimpulkan bahwa secara diskriptif kebiasaan merokok tidak berpengaruh terhadap tekanan darah pekerja di area fabrikasi baja PT Bangun Sarana Baja Gresik tahun 2020. 
Tabel 12

Pengaruh Kebiasaan Minum Beralkohol Terhadap Perubahan Tekanan Darah Pekerja Pada Area Fabrikasi Baja di PT. Bangun Sarana Baja Gresik Tahun 2020.

\begin{tabular}{|c|c|c|c|c|c|c|c|}
\hline \multirow{3}{*}{ No } & \multirow{3}{*}{$\begin{array}{l}\text { Kebiasaan } \\
\text { Minum } \\
\text { Beralkohol }\end{array}$} & \multicolumn{4}{|c|}{ Tekanan Darah } & \multirow{3}{*}{ Jumlah } & \multirow{3}{*}{$\%$} \\
\hline & & \multicolumn{2}{|c|}{ MS } & \multicolumn{2}{|c|}{ TMS } & & \\
\hline & & $\mathbf{N}$ & $\%$ & $\mathbf{N}$ & $\%$ & & \\
\hline 1. & $\mathrm{Ya}$ & 1 & $25 \%$ & 3 & $75 \%$ & 4 & $100 \%$ \\
\hline 2. & Tidak & 3 & $13 \%$ & 21 & $87 \%$ & 24 & $100 \%$ \\
\hline
\end{tabular}

Hasil penelitian tentang kebiasaan minum minuman berakohol terhadap tekanan darah (table 12) dapat diketahui bahwa pekerja dengan kebiasaan minum minuman beralkohol memiliki tekanan darah tidak memenuhi syarat sebanyak $75 \%$, seangkan pekerja yang tidak memiliki kebiasaan menum minuman berakohol lebih besar yaitu sebanyak $87 \%$, sehingga secara diskriptif kebiasaan minu minuman berakohol tidak mempengaruhi tekanan darah tidak menuhi syarat bagi pekerja di area fabrikasi baja PT. PT Bangun Sarana Baja Gresik tahun 2020.

\section{KESIMPULAN}

Kebisingan di area fabrikasi baja PT. Bangun Sarana Baja Gresik tahun 2020 telah melebihi NAB, ada perbedaan yang signifikan tekanan darah pekerja sebelum denagn sesudah terpapar kebisingan baik sistole maupun diastole, dan secara diskriptif nampaknya umur dan masa kerja berpengaruh terhadap tekanan darah, sedangkan kebiasaan merokok dan minum minuman beralkohol secara diskriptif tidak berpengaruh terhadap tekanan daran yang tidak memenuhi syarat.

\section{SARAN}

Disarankan kepada perusahaan untuk melakukan pengendalian sumber kebisingan dan mewajibkan penggunaan Alat Pelindung Diri serta memberikan pelatihan dan penyuluhan kepada tenaga kerja mengenai kesehatan dan keselamatan kerja, mengingat tingkat kesadaran tenaga kerja mengenai pentingnya keselamatan dan kesehatan kerja masih kurang,

\section{DAFTAR PUSTAKA}

Albustomi, Y., \& W, D. A. (2017). Perbedaan Tekanan Darah Sistole dan Diastole Sebelum dan Setelah Kerja Pada Pekerja Yang Terpapar Bising di PT X. JPH RECODE, 1(1), 22-29.

Anizar. (2009). Teknik Keselamatan dan Kesehatan Kerja di Industri. Yogyakarta: Graha Ilmu.
Buchari. 2007. Kebisingan Industri dan Hearing Conservation Program. Universitas Sumatera Utara

Debora, O. (2012). Proses Keperawatan dan Pemeriksaan Fisik. Jakarta: Salemba Medika.

Departemen Kesehatan Republik Indonesia, 2009. Sistem kesehatan Nasional. Jakarta

Hidayat. 2005. Pengaruh Pemakaian APD Telinga Ear plug Terhadap perubahan tekana Darah Akibat Bising di Kecamatan Karanganyar Kabupaten Karanganyar. Skripsi. Semarang : Universitas Diponegoro

Hadi, S. (2014). Faktor-Faktor Yang Mempengaruhi Kenaikan Tekanan Darah Pada Pekerja Yang Terpajan Kebisingan Di PT. "X" Indonesia Tahun 2014.

Ikhwan, W., Mukhlish, N., Sudarmanto, Y., \& Hasan, M. (2018). Pengaruh Kebisingan Terhadap Tekanan Darah dan Nadi pada Pekerja Pabrik Kayu PT. Muroco Jember. Jurnal Kesehatan Lingkungan Indonesia, 17, 112-118. https://doi.org/10.14710/jkli.17.2.112-118

Keputusan Menteri Negara Lingkungan Hidup Nomor : KEP-48/MENLH/11/1996 Tentang Baku Tingkat Kebisingan

Muhammad Amin, Rita Rosari, Y. (2019). Perbedaan Tekanan Darah Sebelum Dan Sesudah Pekerja Terpajan Kebisingan Di Penggilingan Padi Dan Kopi. Journal of Telenursing (JOTING), 1, 27-37. https://doi.org/10.1017/СBO97811074153 24.004

Novi Nur Pratiwi, Winarko dan Narwati (2019) Gema Kesehatan Lingkungan, Volume 16, Nomor 1 (2018) (http://journal.poltekkesdepkessby.ac.id/index.php/KESLING/article/view/ 820/622)

Paramita, Dita Aisyah. 2012. Pengaruh Intensitas Kebisingan Terhadap Kenaikan Tekanan Darah Karyawan (Studi Pada Pelaksanaan Overhaul di PT. PJB Gresik). Skripsi. Surabaya : Universitas Airlangga 
Peraturan Menteri Kesehatan Republik Indonesia Nomor 70 tahun 2016 tentang Standar dan Persyaratan Kesehatan Lingkungan Kerja Industri

Peraturan Menteri Ketenagakerjaan Republik Indonesia Nomor 5 Tahun 2018. Tentang Keselamatan Dan Kesehatan Kerja Lingkungan Kerja

Prasetio, L. 1985. Akustik Lingkungan. Institut Teknologi Sepuluh November Surabaya. Jakarta: Penerbit Erlangga.

Sasongko, Dwi P. 2000. Kebisingan Lingkungan. Semarang: Universitas Diponegoro.

Setiyanto, Tri. 2013. Pengaruh Intensitas Kebisingan Terhadap Kenaikan Denyut Nadi pada Pekerja di PT PERTANI (PERSERO) Cabang Surakarta. Artikel. Surakarta : Universitas Muhammadiyah
Subaris dan Haryono. 2008. Hygiene Lingkungan Kerja. Yogyakarta: Mitra Cendekia Press.

Suma'mur. 2009. Higiene Perusahaan dan Keselamatan Kerja. Jakarta : Sagung Seto.

Suroto, W. 2010.Dampak Kebisingan Lalu Lintas Terhadap Pemukiman Kota (Kasus Kota Surakarta).Jurnal of Rulan and Development.Volume 1, No. 1 Februari 2010

Tarwaka. 2008. Kesehatan dan Keselamatan Kerja Manajemen dan Implementasi K3 di Tempat Kerja. Surakarta : HARAPAN PRESS.

Watson, R. 2002. Anatomi \& Fisiologi untuk Perawat. EGC. Jakarta. 